Vol. 1 No. 2 Agustus 2021, e-ISSN : 2777-0575 P-ISSN : 2777-0583

\title{
UPAYA PENINGKATAN HASIL BELAJAR PESERTA DIDIK PADA ASPEK AKHLAK DENGAN METODE DEMONSTRASI DAN BERMAIN PERAN KELAS IV SD NEGERI 29 SUNGAI KAKAP
}

\author{
SUKRIYANTO \\ SD Negeri 29 Sungai Kakap \\ e-mail : sukriyanto737@gmail.com
}

\begin{abstract}
ABSTRAK
Tujuan penelitian ini adalah untuk mengetahui upaya peningkatan hasil belajar peserta didik pada aspek akhlak dengan metode demonstrasi dan bermain peran kelas IV. Subjek penelitian adalah siswa kelas IV. Teknik pengumpulan data adalah tes dan observasi. Hasil penelitian adalah Hasil temuan penelitian yang diperoleh adalah: Aktivitas peserta didik dalam pembelajaran menunjukkan peningkatan dari siklus ke siklus. Pada siklus I aktivitas peserta didik menunjukkan skor 74,7\%, kemudian pada siklus II meningkat menjadi 84,1\%, Respon peserta didik terhadap pembelajaran dengan metode demonstrasi dan bermain peran ini, mereka menyatakan sangat menyenangkan, tidak jenuh dan mudah memahaminya, Hasil belajar peserta didik mengalami peningkatan yang tergambar dalam perolehan persentase. Perolehan nilai persentase pada siklus I adalah $36,7 \%$ dengan ketuntasan peserta didik berjumlah 11 orang, pada siklus II meningkat menjadi $80 \%$ dengan ketuntasan peserta didik berjumlah 24 orang.
\end{abstract}

Kata Kunci: Hasil Belajar, Metode Demonstrasi, Bermain Peran

\section{PENDAHULUAN}

Pendidikan agama merupakan bagian terpadu yang dimuat dalam kurikulum pendidikan maupun melekat pada setiap mata pelajaran sebagai bagian dari pendidikan nilai. Oleh karena itu nilai-nilai agama akan selalu memberikan corak pada pendidikan nasional (Hasbulllah. 2009: 128). Menurut Undang-Undang No. 20 Tahun 2003 tentang sistem pendidikan Nasional pasal 1 ayat 1 menyatakan bahwa pendidikan adalah usaha sadar dan terencana untuk mewujudkan suasana belajar dan proses pembelajaran agar peserta didik secara aktif mengembangkan potensi dirinya untuk memiliki kekuatan spritual keagamaan, pengendalian diri, kepribadian, kecerdasan, akhlak mulia, serta keterampilan yang diperlukan dirinya, masyarakat, bangsa dan negara. Tujuan pendidikan dirumuskan sesuai dengan Undang-undang No. 20 Tahun 2003, pasal 3, yakni untuk berkembangnya potensi peserta didik, agar menjadi manusia yang beriman dan bertakwa kepada Tuhan Yang Maha Esa, berakhlak mulia, sehat, berilmu, cakap, kreatif, mandiri dan menjadi warga negara yang demokratis serta bertanggung jawab.

Pada dasarnya pendidikan, juga tercantum dalam UU SISDIKNAS Nomor 20 Tahun 2003 yaitu usaha sadar dan terencana untuk mewujudkan suasana belajar dan proses pembelajaran peserta didik secara aktif mengembangkan potensi dirinya untuk memiliki kekuatan spiritual keagamaan, pengendalian diri, kepribadian, kecerdasan akhlak mulia serta keterampilan yang diperlukan dirinya dan masyarakat (Sapri, 2018: 169)

Pada jenjang pendidikan menengah, pendidikan agama merupakan pendidikan wajib. Jadi pendidikan agama dalam sistem pendidkan nasional keberadaannya sangat penting. Persoalan atau tantangan yang dihadapi dalam pelaksanaan pendidikan agama sebagai suatu mata pelajaran di sekolah saat ini adalah bagaimana agar pendidikan agama tidak hanya mengajarkan pengetahuan tentang agama, tetapi dapat mengarahkan peserta didik untuk menjadi manusia yang benar-benar mempunyai kualitas keberagamaan yang kuat. Dengan demikian, materi pendidikan agama tidak hanya menjadi pengetahuan, tetapi dapat membentuk sikap dan kepribadian peserta didik sehingga menjadi manusia yang beriman dan bertakwa dalam arti sesungguhnya, apalagi pada saat-saat seperti sekarang yang 
tampaknya muncul gejala terjadinya pergeseran nilai-nilai yang ada sebagai akibat majunya ilmu pengetahuan dan teknologi (Hasbulllah. 2009: 183).

Standar kompetensi lulusan pada jenjang pendidikan tinggi bertujuan untuk mempersiapkan peserta didik menjadi anggota masyarakat yang berakhlak mulia, memiliki pengetahuan, keterampilan, kemandirian, dan sikap untuk menemukan, mengembangkan, serta menerapkan ilmu, teknoogi dan seni, yang bermanfaat bagi kemanusiaan (Wina Sanjaya. 2008: 154). Mata pelajaran Pendidikan Agama Islam sebuah mata pelajaran yang kedudukannya setara dengan mata pelajaran lain, maka Pendidikan Agama Islam memiliki karakteristik tersendiri. Karakteristik tersebut antara lain sebagai berikut: Pendidikan Agama Islam merupakan mata pelajaran yang dikembangkan dari ajaran-ajaran pokok yang terdapat dalam agama Islam, sehingga Pendidikan Agama Islam merupakan bahagian yang tidak dapat dipisahkan dari ajaran Islam dan Tujuan akhir dari pembelajaran Pendidikan Agama Islam adalah terbentuknya peserta didik yang berakhlak musia. Dengan demikian, pendidikan akhlak adalah jiwa Pendidikan Agama Islam.

Pendidikan akhlak merupakan ruh dari Pendidikan Agama Islam yang merupakan pengembangan dari tujuan pendidikan nasional secara umum. Ini bukan berarti Pendidikan Agama Islam mengabaikan pendidikan jasmani atau pendidikan praktis lainnya, tetapi maksudnya adalah Pendidikan Agama Islam itu menjadi penyeimbang dari kebutuhan peserta didik itu sendiri, karena di samping membutuhkan pendidikan jasmani, akal dan ilmu, mereka juga memerlukan pendidikan mental, budi pekerti, perasaan, kemauan, cita rasa dan kepribadian. Dengan demikian Pendidikan Agama Islam menduduki posisi strategis dalam mempersiapkan sumber daya manusia yang unggul, handal, dan berakhlak.

Dengan demikian tujuan pendidikan Islam adalah pembentukan akhlak dan budi pekerti yang sanggup menghasilkan orang-orang yang bermoral, laki-laki maupun wanita, memiliki jiwa yang bersih, kemauan keras, cita-cita yang benar dan akhlak yang tinggi, mengetahui arti kewajiban dan pelaksanaannya, menghormati hak-hak manusia, mengetahui perbedaan buruk dan baik, menghindari suatu perbuatan yang tercela, dan mengingat Tuhan dalam setiap pekerjaan yang mereka lakukan (Muhammad `Athiyyah Al-Abrasyi. 2003: 113)

Tujuan umum pendidikan adalah mengembangkan kekuatan akhlak anak, menumbuhkan rasa cinta agama, berpegang teguh kepada ajaran-ajarannya, serta berprilaku yang sesuai dengan nilai-nilai agama yang murni. Tujuan pendidikan akhlak yang dirumuskan Ibn Miskawaih adalah terwujudnya sikap batin yang mampu mendorong secara spontan untuk melahirkan semua perbuatan yang bernilai baik (Abudin Nata. 2003: 11). Menurut Ibn Sina, bahwa tujuan pendidikan harus diarahkan pada pengembangan seluruh potensi yang dimiliki seseorang ke arah perkembangan yang sempurna yaitu perkembangan fisik, intelektual dan budi pekerti (Muhammad `Athiyyah Al-Abrasyi. 2003: 67).

Islam sebagai agama samawi yang sempurna mengandung berbagai aspek. Secara umum ada aspek aqidah, aspek ibadah dan aspek ahklak. Seorang muslim yang sejati harus dapat mengamalkan ketiga aspek tersebut secara integral. Misalnya seseorang yang beraqidah benar, maka ia akan beribadah sesuai tuntunan dan sekaligus akan teraktualisasi dalam sikap melalui akhlak yang baik. Ibarat sebuah pohon, aqidah adalah akarnya, ibadah adalah batang, cabang dan rantingnya, maka akhlak adalah daun buah dan bunganya. Dapat dikatakan akhlak adalah hasil dari semua amalan seorang Muslim.

Ajaran Islam adalah petunjuk bagi manusia untuk mewujudkan suatu kehidupan yang penuh rahmat. Bentuk yang nyata dari rahmat Allah itu ialah keselamatan, kesehatan, ketentraman, kesejahtraan, dan kebahagian di dunia dan di akhirat. Hal-hal inilah yang tercakup dalam arti kata "hasanah" yang di dalam hukum Islam disebut "maslahah" (keselamatan).

Salah satu upaya peningkatan iman dan takwa bagi kaum Muslimin itu ialah menampilkan kepribadian dalam berbusana dan berhias serta bertamu dan menerima tamu yang harus sesuai dengan petunjuk dan tuntunan serta selaras dengan ketentuan hukum dan ajaran agama. Khususnya yang berhubungan dengan pakaian, yang berfungsi untuk menutupi aurat dan memperindah jasmani dan manusia. Dijelaskan bahwa Allah telah menyediakan banyak bahan 
baku pakaian atau penutup aurat yang dijadikan bagi manusia agar memenuhi unsur etik dalam kehidupannya.

Menurut ajaran Islam, aurat wanita Islam adalah seluruh badannya, kecuali muka dan dua telapak tangan sehingga wajib bagi seorang wanita Islam memelihara beberapa bagian badannya dan menutup dadanya dengan kerudung. Ilmu fikih menegaskan bahwa aurat lakilaki adalah di antara pusar sampai lutut. Sopan santun atau tata krama berlaku bagi semua orang, baik pria dan wanita, tua dan muda, bahkan anak-anak. Oleh karena itu sopan santun hendaklah dibiasakan sedini mungkin yaitu sejak si anak masih kecil dengan mengambil contoh dan teladan dari orang tuanya serta anggota keluarganya yang lain.

Materi dakwah Rasulullah Saw, sehingga beliau meletakkan dasar-dasar materi dakwah periode Mekkah dengan aspek akhlak. Akhlak yang baik akan mudah menerima kebenaran, oleh karena itu Rasulullah Saw, senantiasa memberi tauladan yang baik kepada sahabat. Mengingat sopan santun atau tata krama dibiasakan sedini mungkin dan berkesenambungan berarti guru selaku pendidik juga bertanggung jawab membentuk tata krama atau sopan santun peserta didik agar menjadi baik dan sesuai dengan ajaran Islam karena tugas guru bukan hanya mengajar saja tetapi juga mendidik.

Mendidik menurut konsep Islam tidak sekedar mengajar, melainkan juga melatih, membiasakan, membimbing memberi dorongan, mengembangkan, menggerakkan, mengarahkan, memberi contoh teladan, dan memfasilitasi proses pembelajaran guna memberdayakan segenap potensi atau daya-daya yang dimiliki peserta didik secara maksimal, karena tujuan pendidikan Islam bukan hanya mengupayakan terbentuknya pribadi yang cerdas dan terampil, tetapi juga bertujuan untuk berkembangnya potensi peserta didik agar menjadi manusia yang beriman dan bertakwa kepada Tuhan Yang Maha Esa, berakhlak mulia dan seterusnya.

Tujuan pokok pendidikan akhlak adalah Pertama, memelihara diri peserta didik agar sepanjang hidupnya tetap berada dalam fitrah Nya, baik dalam arti suci dan bersih dari dosa dan maksiat, maupun dalam arti bersyahadad atau bertauhid kepada Allah Swt. Kedua, menanamkan prinsip- prinsip, kaedah-kaedah, atau norma-norma tentang baik-buruk atau terpuji- tercela ke dalam diri dan kepribadian peserta didik agar mereka berkemampuan memilih untuk menampilkan prilaku yang baik atau terpuji dan menghindari atau meninggalkan semua perilaku buruk atau tercela dalam kehidupannya (Darsono, dkk, 2009: 75)

Sehubungan dengan eksistensi Pendidikan Agama Islam sebagai penyeimbang dari kebutuhan pendidikan peserta didik, pembelajaran Pendidikan Agama Islam pada setiap jenis, jalur dan jenjang pendidikan haruslah memberikan kontribusi dalam pembentukan kepribadian peserta didik, baik dalam aspek kognitif, psikomotor apalagi aspek afektif. Untuk mewujudkan semua itu pembelajaran Pendidikan Agama Islam harus dikemas dengan metode dan strategi pembelajaran yang aktif, kreatif, efektif, menarik, menantang dan menyenangkan.

Rendahnya hasil belajar peserta didik terhadap mata pelajaran Pendidikan Agama Islam pada aspek akhlak khususnya mengenai adab berpakaian dan berhias serta bertamu dan menerima tamu terlihat dalam kehidupan sehari- hari, masih bayak peserta didik yang berpakaian dan berhias serta bertamu dan menerima tamu tidak menunjukkan kesesuai dengan ajaran agama Islam. Terlihat dari contoh peserta didik yang berpakaian menutup aurat yang terlalu ketat, nampak pusat dan celana, kainnya yang terlalu tipis sehingga mengundang pandangan yang tidak enak bagi yang memandangnya. Dan juga banyak peserta didik yang datang ke rumah guru cara bertamunya kurang sopan dan tidak sesuai dengan anjuran ajaran Islam. Terlihat juga banyak peserta didik yang masuk kantor majelis guru yang langsung saja masuk tanpa mengucapkan salam ataupun permisi.

\section{METODE PENELITIAN}

Alat pengumpul data pada teknik observasi adalah daftar cek (cheek list) yang mempergunakan sebuah daftar yang memuat nama-nama observer disertai jenis-jenis gejala yang akan diamati. Alat pengumpulan data pada teknik studi dokumentasi yang digunakan 
seperti kamera, data-data siswa dan sebagainya. Alat pengumpulan data dalam teknik evaluasi adalah lembar soal/lembar tes yang akan dikelolah dengan teknik penskoran dan penilaian. Penskoran adalah suatu proses perubahan jawaban-jawaban tes menjadi angka-angka (mengadakan kuantifikasi). Sedangkan penilaian adalah proses menentukan nilai suatu obyek dengan menggunakan ukuran atau kriteria tertentu, seperti Baik, Sedang, Jelek. Angka-angka hasil penskoran itu kemudian diubah menjadi nilai-nilai melalui proses pengolahan tertentu. Penggunaan simbol untuk menyatakan nilai-nilai itu ada yang dengan angka, seperti angka dengan rentangan $0-10,0-100$ dan ada pula yang menggunakan huruf $\mathrm{A}, \mathrm{B}, \mathrm{C}, \mathrm{D}$, dan $\mathrm{E}$. Cara menskor hasil tes biasanya disesuaikan dengan bentuk soal-soal tes yang dipergunakan, apakah tes objektif atau tes essay.

Hasil observasi dianalisis dengan analisis deskriptif berdasarkan hasil observasi dan refleksi dengan indikator kinerja peserta didik dalam pembelajaran. Adapun Indikator kinerja peserta didik dalam pembelajaran dapat dibuat dalam bentuk tabel sebagai berikut:

Tebel 1. Indikator Keberhasilan (\%)

\begin{tabular}{|l|c|l|}
\hline \multicolumn{1}{|c|}{ Aspek } & $\begin{array}{c}\text { Indikato } \\
\mathrm{r}\end{array}$ & \multicolumn{1}{|c|}{ Alat Ukur } \\
\hline $\begin{array}{l}\text { Aktivitas siswa dalam pembelajaran } \\
\text { metode demonstrasi dan bermain peran } \\
\text { dalam pembelajaran PAI }\end{array}$ & $75 \%$ & $\begin{array}{l}\text { Menggunakan format observasi } \\
\text { aktivitas belajar siswa dengan } \\
\text { menggunakan metode } \\
\text { demonstrasi dan bermain peran. }\end{array}$ \\
\hline $\begin{array}{l}\text { Aktivitas guru dalam menggunakan } \\
\text { metode demonstrasi dan bermain peran } \\
\text { pada mata pelajaran PAI }\end{array}$ & $75 \%$ & $\begin{array}{l}\text { Menggunakan format observasi } \\
\text { aktivitas guru dalam menerapkan } \\
\text { metode demonstrasi dan bermain } \\
\text { peran. }\end{array}$ \\
\hline $\begin{array}{l}\text { Hasil belajar siswa pada mata pelajaran PAI } \\
\text { Standar Kompetensi akhlak tercela dengan } \\
\text { menggunakan metode demonstrasi dan } \\
\text { bermain peran. }\end{array}$ & $75 \%$ & $\begin{array}{l}\text { Penggunakan tes hasil belajar. } \\
\text { - } \\
\text { enilaian skala sikap }\end{array}$ \\
\hline
\end{tabular}

\section{HASIL DAN PEMBAHASAN}

\section{A. Pengamatan (Observasi) Siklus I}

Pengamatan yang dilakukan terhadap hasil belajar siswa dengan menerapkan metode demonstrasi dan bermain peran: mencatat tindakan peserta didik ketika guru menjelaskan materi pokok, mencatat respon peserta didik ketika guru mendemonstrasikan materi, mencatat respon peserta didik ketika kelompok peserta didik bermain peran tentang materi, mencatat prilaku peserta didik ketika bekerjasama dalam kelompok.

Tabel 2. Hasil Belajar Peserta Didik Pada Siklus I (Pertama)

\begin{tabular}{|l|l|l|l|l|}
\hline No & Nilai & Jumlah (F) & Presentase (\%) & Keterangan \\
\hline 1 & $91-100$ & 3 & $10 \%$ & Sangat Kompeten \\
\hline 2 & $81-90$ & 5 & $16,7 \%$ & Kompeten \\
\hline 3 & $75-80$ & 3 & $10 \%$ & Cukup Kompeten \\
\hline 4 & $<75$ & 19 & $63.3 \%$ & Tidak Kompeten \\
\hline & Jumlah & 30 & $100 \%$ & \\
\hline
\end{tabular}

Keterangan:

Jumlah: Jumlah total skor indikator atau aspek yang diamati.

Total persentase dari aktivitas demonstrasi dan bermain peran peserta didik adalah:

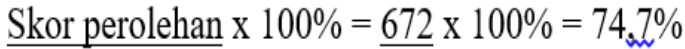

Skor maksimal 900 
Analisis data yang diperoleh dari observasi dengan menggunakan analisis deskriptif persentase. Skor yang diperoleh dari masing-masing indikator tiap- tiap peserta didik dijumlahkan dan hasilnya disebut skor. Adapun cara menghitung persentase aktivitas peserta didik adalah membagi jumlah skor aktivitas dengan skor total aktivitas yang kemudian dikalikan dengan $100 \%$.

Dengan demikian tingkat aktivitas peserta didik yang ditemukan pada siklus I (pertama) dapat dikatakan belum mencapai indikator keberhasilan dalam penelitian tindakan kelas, karena indikator yang peneliti tetap $80 \%$. Jadi peneliti simpulkan bahwa pada siklus I (pertama) aktivitas peserta didik dalam mendemonstrasikan dan memerankan masih rendah. Angka 74,7\% merupakan angka kumulatif dari indikator sikap, keaktifan, respon, kemampuan, kerjasama dan kebenaran syariat peserta didik dalam mengikuti pembelajaran dengan metode demonstrasi dan bermain peran.

\section{B. Hasil Penelitian Siklus II}

Hasil observasi terhadap aktivitas peserta didik pada siklus II (kedua) dapat dilihat pada tabel di bawah ini.

Tabel 3. Hasil Aktivitas Demonstrasi dan Bermain Peran Peserta Didik

\begin{tabular}{|l|l|l|l|l|}
\hline \multirow{2}{*}{ No } & \multirow{3}{*}{ Aktivitas } & SIKLUS & \multicolumn{2}{l|}{} \\
\cline { 3 - 5 } & Jumlah & Rata-rata & Persentase (\%) \\
\hline 1 & Sikap & 128 & 4,3 & $85,3 \%$ \\
\hline 2 & Keaktifan & 127 & 4,2 & $84,7 \%$ \\
\hline 3 & Respon & 122 & 4,1 & $81,3 \%$ \\
\hline 4 & Kemampuan & 122 & 4,1 & $81,3 \%$ \\
\hline 5 & Kerja Sama & 126 & 4,2 & $84 \%$ \\
\hline 6 & Kebenaran Syariat & 132 & 4,4 & $88 \%$ \\
\hline & Jumlah & 757 & 25,3 & $504,6 \%$ \\
\hline
\end{tabular}

Keterangan:

Jumlah : Jumlah total skor indikator atau aspek yang diamati.

Total persentase dari aktivitas demonstrasi dan bermain peran peserta didik adalah:

$$
\frac{\text { Skor perolehan }}{\text { Skor maksimal }} \times 100 \%=\underline{757} \times 100 \%=84,1 \%
$$

Analisis data yang diperoleh dari observasi dengan menggunakan analisis deskriptif persentase. Skor yang diperoleh dari masing-masing indikator tiap- tiap peserta didik dijumlahkan dan hasilnya disebut skor. Adapun cara menghitung persentase aktivitas peserta didik adalah membagi jumlah skor aktivitas dengan skor total aktivitas yang kemudian dikalikan dengan $100 \%$.

Dengan demikian tingkat aktivitas peserta didik yang ditemukan pada siklus II (kedua) dapat dikatakan sudah mencapai indikator keberhasilan dalam penelitian tindakan kelas, karena indikator yang peneliti tetap $80 \%$. Jadi peneliti simpulkan bahwa pada siklus II (kedua) aktivitas peserta didik dalam mendemonstrasikan dan memerankan dikatakan tuntas, namun perlu ditingkatkan lagi. Angka 84,1\% merupakan angka kumulatif dari indikator sikap, keaktifan, respon, kemampuan, kerjasama dan kebenaran syariat peserta didik dalam mengikuti pembelajaran dengan metode demonstrasi dan bermain peran.

Sikap yang dimaksud adalah sikap peserta didik dalam berprilaku dan menghargai teman waktu proses pembelajaran, misalnya mendengar pendapat temannya, tidak membuat keributan, dan berprilaku sopan saat proses pembelajaran. Sikap ini terlihat hingga 85,3\%. Selanjutnya terlihat tingkat keaktifan peserta didik dalam mengemukakan pendapat dan menyatakan ide dengan jelas mencapai $84,7 \%$. Respon peserta didik dalam menanggapi permasalahan yang terjadi dalam proses pembelajaran, respon ini mencapai $81,3 \%$. Kemampuan peserta didik dalam melaksanakan proses pembelajaran mencapai 81,3\%. Kerja 
sama peserta didik dengan peserta didik lainnya dan sesama kelompok dalam proses pembelajaran, ini terlihat mencapai $84 \%$, dan kebenaran syariah yaitu kebenaran peserta didik menurut ajaran Islam dalam proses pembelajaran mencapai $88 \%$.

Tabel 4. Hasil Belajar Peserta Didik Pada Siklus II

\begin{tabular}{|l|l|l|l|l|}
\hline No & Nilai & Jumlah (F) & Presentase (\%) & Keterangan \\
\hline 1 & $91-100$ & 6 & $20 \%$ & Sangat Kompeten \\
\hline 2 & $81-90$ & 6 & $20 \%$ & Kompeten \\
\hline 3 & $75-80$ & 12 & $40 \%$ & Cukup Kompeten \\
\hline 4 & $<75$ & 6 & $20 \%$ & Tidak Kompeten \\
\hline & Jumlah & 30 & $100 \%$ & \\
\hline
\end{tabular}

Dari tabel di atas ketuntasan peserta didik mencapai $80 \%$ yang terdiri dari $20 \%$ sangat kompoten, $20 \%$ kompoten dan $40 \%$ cukup kompoten. Sedangkan yang tidak tuntas mencapai 20\%. Hasil tersebut menunjukkan bahwa pada siklus II (kedua) secara klasikal peserta didik sudah tuntas. Data tabel di atas merupakan analisis peneliti dari jawaban-jawaban peserta didik pada waktu dilakukan uji kompetensi.

\section{Pembahasan Penelitian}

Berdasarkan temuan-temuan penelitian dari pernerapan model pembelajaran metode demonstrasi dan bermain peran dan hasil belajar siswa tersebut di atas, maka dapat dijelaskan. Beranjak dari hasil-hasil atau temuan dalam tindakan kelas yang sudah didiskripsikan di atas, peneliti menganalisis perkembangan hasil setiap siklus sehingga akan tergambar perkembangan hasil tindakan siklus I dan II, titik perbedaan dan persamaannya, serta terjadi peningkatan dari siklus ke siklus.cara, jalan dan teknik yang digunakan oleh guru dalam proses pembelajaran agar peserta didik dapat mencapai tujuan pembelajaran atau menguasai kompetensi tertentu yang dirumuskan dalam silabus mata pelajaran (Arifin, 2006: 121).

\section{Hasil Observasi Aktivitas Peserta Didik}

Pada siklus I (pertama), tingkat aktivitas belajar peserta didik dalam pembelajaran Pendidikan Agama Islam: aspek akhlak materi sikap Jujur dengan menggunakan metode demonstrasi dan Bermain peran belum mencapai katagori kriteria ketuntasan, karena rata-rata skor dari indikator sikap, keaktifan, respon, kemampuan, kerjasama dan kebenaran syariat peserta didik dalam mengikuti pembelajaran hanya mendapat persentase 74,7\%.

Sedangkan indikator keberhasilan penelitian tindakan kelas ini adalah $80 \%$. Pada siklus II (kedua) aktifitas belajar peserta didik mengalami peningkatan dari $74,7 \%$ menjadi $84,1 \%$. Jadi aktifitas peserta didik siklus II (kedua) dikatakan sudah mencapai ketuntasan secara individu maupun secara klasikal.

Demikian juga halnya dengan hasil temuan pada siklus III (ketiga), aktivitas belajar peserta didik terlihat baik/sangat tinggi. Hal ini disebabkan peserta didik sudah memahami teknik mengikuti pembelajaran dengan metode demonstrasi dan bermain peran. Untuk melihat terjadinya peningkatan aktifitas peserta didik dari siklus ke siklus dapat dilihat dari tabel berikut ini

Tabel 5. Perbandingan Aktivitas Peserta Didik Persiklus

\begin{tabular}{|l|l|l|l|}
\hline No & Indikator & Siklus I & Siklus II \\
\hline 1 & Sikap & $74 \%$ & $85,3 \%$ \\
\hline 2 & Keaktifan & $74 \%$ & $84,7 \%$ \\
\hline 3 & Respon & $76 \%$ & $81,3 \%$ \\
\hline 4 & Kemampuan & $73,3 \%$ & $81,3 \%$ \\
\hline 5 & Kerjasama & $75.3 \%$ & $84 \%$ \\
\hline 6 & Kebenaran syari ah & $75,3 \%$ & $88 \%$ \\
\hline \multicolumn{2}{l}{ Rata-rata Persentase } & $74,7 \%$ & $84,1 \%$ \\
\hline
\end{tabular}


Pada tabel di atas terlihat secara keseluruhan indikator atau aspek yang diamati dari siklus ke siklus mengalami peningkatan persentase. Baik unsur sikap, keaktifan, respon, kemampuan, kerjasama dan kebenaran syariat peserta didik dalam pembelajaran metode demonstrasi dan bermain peran.

Aspek aktivitas peserta didik terjadi peningkatan dari sebelumnya $74,7 \%$ menjadi $84,1 \%$ menjadi $92 \%$. Kondisi ini didukung dengan beberapa faktor yang dapat mempengaruhi hasil belajar peserta didik. Misalnya pada setiap tindakan peneliti melakukan tahap perencanaan pembelajaran yang matang mengikuti tahap-tahap pelaksanaan pembelajaran metode demonstrasi dan bermain peran. Selain itu peserta didik telah mengemukakan bahwa mereka cepat memahami pelajaran Pendidikan Agama Islam aspek akhlak materi berpakaian dan berhias serta bertamu dan menerima tamu melalui pembelajaran metode demonstrasi dan bermain peran.

Guru menilai efektivitas dan keberhasilan bermain peran. Dalam melakukan evaluasi ini, guru dapat menggunakan komentar evaluasi dari peserta didik, catatan-catatan yang dibuat oleh guru selama berlangsungnya bermain peran. Berdasarkan evaluasi tersebut, selanjutnya guru dapat menentukan tingkat perkembangan pribadi, sosial, dan akademik para peserta didiknya (Iskandar, 2009)

Setiap tujuan pembelajaran harus mengandung domain/ ranah kognitif, afektif dan psikomotorik. Domain kognitif meliputi kemampuan berpikir, termasuk di dalamnya kemampuan mengingat, memahami, mengaplikasi, menganalisis, mensintesis dan mengevaluasi. Domanin afektif meliputi kemampuan watak perilaku, seperti perasaan, minat, sikap, emosi, dan nilai. Domain psikomotorik meliputi imitasi, manipulasi, presisi, artikulasi, dan naturalisasi (Kasbollah, 2000)

Indikasi munculnya aktivitas belajar peserta didik ditandai dengan sebagian besar atau lebih dari $80 \%$ (indikator keberhasilan tindakan kelas) bersikap baik terhadap peserta didik lain $94,7 \%$, aktif mengikuti pembelajaran $89,3 \%$, memberi respon terhadap permasalahan $91,3 \%$, kemampuan dalam pembelajaran $90,7 \%$, bekerjasama dalam kelompok $90,7 \%$ dan kebenaran syariat dalam mendemonstrasikan serta memerankan materi 95,3\%.

\section{Hasil Belajar Peserta Didik}

Pada awalnya siklus I, hasil belajar peserta didik belum mencapai kompetensi yang diharapkan karena hasil ketuntasan peserta didik hanya mencapai 37,7\%. Selanjutnya pada siklus II (kedua), ketuntasan peserta didik meningkat mencapai 80\%. Berarti pada siklus II nilai sudah mencapai ketuntasan secara klasikal yaitu $80 \%$. Ini berarti pembelajaran jujur berhasil dengan menggunakan metode demonstrasi dan bermain peran.

Menyajikan dan menyuguhkan materi pelajaran melalui metode ceramah adalah media yang bagus di dalam memperoleh dan menuntut ilmu Akan tetapi metode ini akan bisa mencapai hasil gemilang bila bergabung dengan metode praktek/demonstrasi. Salah satu kelebihan metode demonstarasi adalah: "keaktifan dan pengalaman peserta didik akan bertambah, karena peserta didik ikut membantu pelaksanaan suatu demonstrasi sehingga ia menerima pengalaman yang bisa mengembangkan kecakapannya, dan pelajaran yang diberikan lebih tahan lama (Fu’ad bin Abdul Aziz asy-Syalhub, 2008: 103)

Metode demonstrasi ini adalah metode mengajar dengan cara memperagakan barang, kejadian, aturan, dan urutan melakukan suatu kegiatan, baik secara langsung maupun melalui penggunaan media pengajaran yang relevan dengan pokok bahasan yang sedang disajikan. Tujuan pokok menggunakan metode demonstrasi dalam proses pembelajaran adalah untuk memperjelas pengertian konsep dan memperlihatkan cara melakukan sesuatu atau proses terjadinya sesuatu. Metode bermain peran pada dasarnya melibatkan peserta didik untuk memerankan atau mendemonstrasikan tingkah laku manusia dalam hubungannya dengan masalah sosial. Metode ini dapat dipergunakan di dalam mempraktik isi pelajaran yang baru, mereka diberi kesempatan seluas-luasnya untuk memerankan sehingga menemukan kemungkinan masalah yang akan dihadapi dalam pelaksanaan sesungguhnya. 
Metode merupakan cara yang digunakan untuk mengimplementasikan rencana yang sudah disusun dalam kegiatan nyata agar tujuan yang telah disusun tercapai secara optimal. Ini berarti, metode digunakan untuk merealisasikan strategi yang telah ditetapkan. Dengan demikian, metode dalam rangkaian sistem pembelajaran memegang peran yang sangat penting (Abdurrahman, 2003:78). Keberhasilan implementasi strategi pembelajaran sangat tergantung pada cara guru menggunakan metode pembelajaran, karena suatu strategi pembelajaran hanya mungkin dapat diimplementasikan melalu penggunaan metode pembelajaran (Suharsimi, 2002: 54).

Dari penjelasan di atas terbukti bahwa ketika pembelajaran bersifat teacher centered maka perolehan hasil belajar jauh dibawah batas kriteria ideal ketuntasan minimal. Tetapi setelah dilakukan pembelajaran yang bersifat teacher centered beralih menjadi student centered, peserta didik terpacu untuk beraktivitas karena metode demonstrasi dan bermain peran memberi peluang yang besar kepada mereka untuk bekerja sama, berpartisipasi, dan beraspirasi.

\section{KESIMPULAN}

Berdasarkan data yang diperoleh dari hasil observasi dan tes hasil belajar sebagaimana yang telah dipaparkan, maka untuk menjawab rumusan masalah dalam penelitian tindakan kelas ini dapat dikemukakan kesimpulan sebagai berikut: Aktivitas peserta didik selama mengikuti proses pembelajaran dengan menerapkan metode demonstrasi dan bermain peran menunjukkan peningkatan yang memuaskan. Hal ini terlihat dari hasil persentase peserta didik pada siklus I (pertama) $74,7 \%$ dan pertemjuan siklus II (kedua) menjadi $84,1 \%$. Respon peserta didik terhadap proses pembelajaran dengan penerapan metode demonstrasi dan bermain peran pada materi berpakain dan berhias serta bertamu dan menerima tamu, menunjukkan peserta didik merasa senang dan mudah memahami materi yang diterapkan penelitin. Hasil belajar peserta didik mengalami peningkatan untuk kategori sangat baik dari $36,7 \%$ pada tes akhir pertemuan pertama menjadi $80 \%$ pada tes akhir pada pertemuan kedua dan menjadi $90 \%$.

\section{DAFTAR PUSTAKA}

Abror, Abdurrahman. (2003). Psikologi Pendidikan. Yogyakarta: PT Tiara Wacana.

Al-Abrasyi.,’A.,M. (2003). Prinsip Prinsip Dasar Pendidikan Islam. Bandung: Pustaka Setia

Arifin. (2006). Ilmu Pendidikan Islam, Jakarta : Bumi Aksara, cet. ke-4.

Asy-Syalhub., Fu’ad bin Abdul Aziz. (2008). Begini Seharusnya Menjadi Guru. Jakarta: Darul Haq.

Darsono., dkk. (2009). Belajar dan Pembelajaran. Semarang: CV IKIP Semarang Press.

Hamalik., Oemar. (2008). Perencanaan Pengajaran Berdasarkan Pendekatan Sistem. Jakarta: Bumi Aksara.

Hasbulllah. (2009). Dasar-Dasar Ilmu Pendidikan. Jakarta: PT Raja Grafindo Persada.

Iskandar. (2009). Penelitian Tindakan Kelas. Jambi: GP Press

Kasbollah. (2000). Penelitian Tindakan Kelas. Jakarta: Rienike Cipta.

Nata., Abudin. (2003). Pemikiran Para Tokoh Pendidikan Islam. Jakarta: PT Raja Grafindo Persada.

Rusman. (2010). Model-Model Pembelajaran Mengembangkan Profesionalisme Guru. Jakarta: Rajawali Pers.

Sanjaya., Wina. (2008). Kurikulum dan Pembelajaran: Teori dan Praktek Pengembangan Kurikulum Tingkat Satuan Pendidikan. Jakarta: Kencana Prenada Media Group

Sapri. (2018). Perkembangan Psikologi Siswa dalam Pendidikan Islam. Priceedings ABKIN: International Conference on Guidance and Counseling (ICGC). Multicultural Guidance and Counseling 